\title{
Tree species susceptibility to leaf-cutting ants attack in carbon neutralization plantations
}

\author{
Vicente Toledo Machado de MORAIS JÚNIOR ${ }^{1}$, Laércio Antônio Gonçalves JACOVINE ${ }^{1}$, \\ Mateus Comine Frades da SILVA ${ }^{1}$, Bruno Leão Said SCHETTINI ${ }^{1 *}$, Maria Paula Miranda Xavier RUFINO ${ }^{1}$, \\ Indira Bifano COMINI ${ }^{1}$, Paulo Henrique VILLANOVA ${ }^{1}$, Samuel José Silva Soares da ROCHA ${ }^{1}$ \\ ${ }^{1}$ Federal University of Viçosa, Viçosa, MG, Brazil. \\ *E-mail: blsschettini@gmail.com \\ (ORCID: 0000-0001-5227-1951; 0000-0001-5485-3090; 0000-0003-2717-0635; 0000-0001-6510-4511; \\ 0000-0001-6594-2152; 0000-0003-1815-5783; 0000-0002-4187-2740; 0000-0001-6686-1936)
}

Recebido em 23/06/2021; Aceito em 16/12/2021; Publicado em 23/12/2021.

\begin{abstract}
Greenhouse gas (GHG) emissions neutralize planting are one of the options for climate changes mitigating. Leaf-cutter ants attack is a threat to the plantations proper development. Ants have selective foraging, which makes it important to know this selectivity and, thus, choose more suitable species to neutralization planting compose. Thus, the goal of the present study was to evaluate the tree species susceptibility to be attacked by leaf-cutter ants in carbon neutralization plantations. The study was carried out in mixed plantations in Viçosa-MG and a classification was created for the present species. The Damage Index (DI) was created by multiplying the Mean of Severity (MS) and the Frequency of Attacks (FA). The species were classified according to the indication for neutralization plantations (indicated, moderately indicated, and not indicated) and potential species for the extraction of natural insecticides. From the 59 species evaluated, 22 were classified as suitable for neutralization plantations, 6 as moderately indicated, 24 as not indicated, and 7 as potential species for extracting natural insecticides.
\end{abstract}

Keywords: forest carbon; pest control; carbon offset; mixed plantings.

\section{Susceptibilidade de espécies arbóreas ao ataque de formigas cortadeiras em plantações de neutralização de carbono}

\begin{abstract}
RESUMO: O plantio para neutralizar as emissões de gases de efeito estufa (GEE) é uma das opções para mitigar as mudanças climáticas. O ataque de formigas cortadeiras é uma ameaça ao bom desenvolvimento dessas plantações. As formigas possuem forrageamento seletivo, o que torna importante conhecer essa seletividade e, assim, escolher espécies mais adequadas para compor o plantio de neutralização. Assim, o objetivo do presente estudo foi avaliar a susceptibilidade de espécies arbóreas ao ataque de formigas cortadeiras em plantios de neutralização de carbono. O estudo foi realizado em plantios mistos do programa Carbono Zero em Viçosa-MG e, com base nessa avaliação, foi criada uma classificação para as espécies presentes. O Índice de Danos (DI) foi criado pela multiplicação da Média de Severidade (MS) e da Frequência de Ataques (FA). As espécies foram classificadas quanto à indicação para plantios de neutralização (indicada, moderadamente indicada e não indicada) e espécies potenciais para extração de inseticidas naturais. Das 59 espécies avaliadas, 22 foram classificadas como aptas para plantios de neutralização, 6 como moderadamente indicadas, 24 como não indicadas e 7 como espécies potenciais para extração de inseticidas naturais.

Palavras-chave: carbono florestal; controle de pragas; compensação de carbono; plantios mistos.
\end{abstract}

\section{INTRODUCTION}

The increase in greenhouse gas (GHG) emissions resulting from the burning of fossil fuels (MAHBUB et al., 2019), agricultural activities (TUBIELLO, 2019) and the degradation of terrestrial environments, cause climate changes on a global scale (ZHENG et al., 2019). The intensification of the greenhouse effect is one of the causes of the highest concentration of GHG in the atmosphere (LI et al., 2019) and, in this context, the removal of CO2 in the atmosphere and its fixation in the form of biomass by trees is one of the viable options for mitigating GHG emissions (DIMOBE et al., 2019). Plantations can neutralize activities that generate quantifiable GHG emissions, based on some strategies (MORAIS JUNIOR et al., 2019).
Among the many challenges to overcome in planting with tree species for carbon neutralization, the control of leafcutter ants stands out. Leaf-cutter ants are pests that cause a significant negative impact (ZANETTI et al., 2014), as they defoliate trees, cut off sprouting buds, cause leggy seedlings and occur throughout the year. Leaf-cutter ants, in natural environments, cause the removal of leaf area in plants (ELIZALDE et al., 2019), which results in decreases in the photosynthetic rate, influencing the shape of the bole, the quantity and quality of the wood produced and even influencing the survival of damaged trees. Ants of the genera Atta fabricius and Acromyrmex mayr are the ones that cause the 
most damage and losses (RABELING et al., 2019; SEGRE; TAYLOR, 2019).

The search for plants resistant to insect attack is a viable alternative to contain pest populations, without causing damage to the environment and without burden to producers (SINGH; KAUR, 2018), which are not restricted only to decreased production, but it also affects the resistance of plants, leaving them more vulnerable to new attacks (CABRAL, 2015).

Leaf-cutter ants have selectivity in choosing attacked plants (ARENAS; ROCES, 2016). This selective capacity is manifested during foraging, when choosing certain species, and even, certain origins of the same forest species. Although leaf-cutter ants are highly polyphagous insects, some vegetables escape their attack almost completely because they probably have chemical defenses against the ants themselves, their fungus, or both. The selectivity of ants is related to the physical properties of the leaves, such as: the presence and density of trichomes, thickness and hardness, the latter two being related to water content. Leaf-cutter ants also prefer pioneer plant species, this is probably due to their low level of chemical defenses and their high nutritional content (COLEY et al., 1985).

The increase in the number of works in the control areas is constant, especially related to the resistance of plants, in an attempt to seek alternatives, or even to make possible an association of different control strategies for leaf-cutter ants. Thus, the objective was to evaluate the susceptibility of tree species to the attack by leaf-cutter ants in carbon neutralization plantations and to create a list that classifies the resistance of tree species to the attack of these insects.

\section{MATERIAL AND METHODS}

The study was conducted at the GHG emissions neutralization plantations of the Carbono Zero Program belonging to the Federal University of Viçosa (UFV), at the UFV Open Space of Events, in Viçosa-MG (2045'35 "S and $\left.42^{\circ} 52^{\prime} 29^{\prime \prime} \mathrm{O}\right)$.

The climate in the region is the Cwa type, according to the Köppen system, that is, mesothermal with hot and rainy summers, and cold and dry winters. Red Latosol and Yellow Alico soils predominate in the region on the tops of the hills and Red-Yellow Podzolics on the terraces, the relief is characterized by hills in the form of spikes, sectioned by the natural drainage network and altitudes ranging from $650 \mathrm{~m}$ to $800 \mathrm{~m}$.

The experiment was carried out in an area that has a history of occurrence of leaf-cutter ants of the species Atta sexdens (Hymenoptera: Formicidae) with impacts on tree individuals (MORAIS JUNIOR et al., 2019). Whenever necessary, the combat was carried out with the use of sulfluramid-based insecticides. Evidence of high infestation is the presence of regenerating forests of Mabea fistulifera Mart., neighboring the planting areas, which have a symbiotic relationship with leaf-cutter ants, close to the plantations (PETERNELLI et al., 2004).

The plantations started in 2010, with one per year, with a combination of forest species native to the region (Table 1), spaced $2 \mathrm{~m} \times 2 \mathrm{~m}$. The neutralization plantations in the evaluation period were $7,6,5,4,3$ and 2 years old, respectively. Most planting areas were covered by Urochola decumbens (Stapf) R.D. Webster. The area was mowed to reduce competition and 30 days before planting, the fight against leaf-cutter ants was carried out using ant bait $(0.3 \%$ sulfluramid) and anticide was applied every 5 months $(0.3 \%$ sulfluramid) at the beginning and at the end of each planting line. The monitoring of the area to control leaf-cutter ants, crowning of the seedlings and controlling the scrubland were performed periodically.

Biweekly assessments were carried out to evaluate the incidence and severity of damage leaf-cutter ants attacks on plants. Each plant was evaluated individually and always by the same evaluator, with the same evaluation criteria.

The incidence and severity were evaluated in the following plant compartments: leaves, barks, trunks, branches, flowers, fruits, seeds, and exposed roots. The herbivorism caused by leaf-cutter ants fits in the following cases: partial leaf loss with semilunar shape on the leaf, leaves cut between two consecutive evaluations and direct observation of the action of leaf-cutter ants cutting or transporting the leaves.

The degree of severity and the incidence of damage to each tree were assessed according to the following scale of scores: 0 - there was no injury/damage; 1 - there was at least a little damage by leaf-cutter ants anywhere in the tree; 3 there was an intermediate situation of damage or a situation of doubt between note 1 and note 5; 5 - there was an exaggerated amount of damage caused by leaf-cutter ants anywhere in the tree.

The analyses were performed excluding individuals who died or suffered attacks by agents other than leaf-cutter ants. The initial number of individuals of each species that were assessed regarding the impacts of herbivorism by leaf-cutter ants corresponded to the initial number of seedlings planted, subtracting the excluded individuals (FERREIRA, 2015). From the records of attacks by leaf-cutter ants, the mean of severity (MS) and the frequency of attacks (FA) per individual were calculated for each species, and a Damage Index (DI) was created: DI $=\mathrm{MS} * \mathrm{FA}$. This index was used to classify speciesThe classified species were divided into four groups (Table 2).

Table 2. Classification of species according to their damage index. Tabela 2. Classificação das espécies de acordo com seu índice de dano.

\begin{tabular}{lc}
\hline \multicolumn{1}{c}{ Classification of species } & ID \\
\hline Potential for extraction of natural insecticides & $<0,04$ \\
Less susceptible to leaf-cutting ants & $0,04<0,39$ \\
Moderately susceptible to leaf-cutter ants attack & $0,40<0,60$ \\
Highly susceptible to leaf-cutter ants & $>0,60$ \\
\hline
\end{tabular}

In the cases where the same species were analyzed in more than one plantation, for classification purposes, the highest score was considered.

\section{RESULTS}

In planting 1, Zeyheria tuberculosa was the species with the highest DI. Dalbergia brasiliensis, Adenanthera pavonina and Inga vera were species with considerable damage (Table 3). Psidium cattleyanum, Schinus molle, Eremanthus erythropappus, Cedrela fissilis and Syzygium cumini were not attacked. In plantation 2, Citharexylum myrianthum was the species with the highest MS followed by Pleroma granulosum and Genipa infundibuliformis. Pseudopiptadenia contorta and Peltophorum dubium were the least attacked species in this planting. The 3 years old planting showed the highest damage index for the species evaluated. Ceiba speciosa was the species that suffered the greatest attack. Citharexylum myrianthum and Genipa infundibuliformis also stood 
out as the most attacked. Peltophorum dubium and Anadenanthera colubrina var. cebil were the species with the lowest rates, repeating the low attack rates in relation to the other species (Table 3).

Table 1. Number of individuals and species identified in each of the neutralization plantations evaluated.

Tabela 1. Número de indivíduos e espécies identificados em cada plantio de neutralização avaliado.

\begin{tabular}{|c|c|c|c|c|c|c|c|}
\hline Species & Family & 10 & 11 & 12 & 13 & 14 & 15 \\
\hline Adenanthera pavonina L. & Fabaceae & 11 & 3 & 4 & & & \\
\hline Albizia niopoides (Spruce ex Benth.) Burkart & Fabaceae & 26 & 17 & 49 & & & \\
\hline Albizia niopoides (Spruce ex Benth.) Burkart & Fabaceae & & & & 12 & 15 & \\
\hline Amburana cearenses (Allemão) A.C. Sm. & Fabaceae & & & & & & 7 \\
\hline Anadenanthera colubrina (Vell.) Brenan & Fabaceae & & & & & & 16 \\
\hline Anadenanthera colubrina var. cebil (Griseb.) Altschul & Fabaceae & 27 & 29 & 52 & 15 & 16 & 6 \\
\hline Andira anthelmia (Vell.) Benth & Fabaceae & 10 & 7 & 16 & & & \\
\hline Apuleia leiocarpa (Vogel) J.F.Macbr. & Fabaceae & & & & & 12 & \\
\hline Pachira glabra Pasq. & Malvaceae & & 4 & & 14 & 16 & 15 \\
\hline Libidibia ferrea var. leiostachya (Benth.) L.P.Queiroz & Fabaceae & & & & & & 11 \\
\hline Cenostigma pluviosum (DC.) E. Gagnon \& G.P. Lewis & Fabaceae & & & & 1 & 5 & \\
\hline Cariniana legalis (Mart.) Kuntze & Lecythidaceae & & & & 2 & & \\
\hline Cassia grandis L.f. & Fabaceae & & & & 13 & 11 & 8 \\
\hline Cedrela fissilis Vell. & Meliaceae & 3 & & & 7 & & 5 \\
\hline Ceiba speciosa (A. St.-Hil.) Ravenna & Malvaceae & & & 6 & 12 & 20 & \\
\hline Centrolobium tomentosum Guillem. ex Benth. & Fabaceae & & & & & 15 & \\
\hline Clitoria fairchildiana R.A. Howard & Fabaceae & & & & & & 8 \\
\hline Colubrina glandulosa Perkins & Rhamnaceae & 11 & 4 & & 13 & 11 & \\
\hline Copaifera langsdorffii Desf. & Fabaceae & & & & & & \\
\hline Cybistax antisyphilitica (Mart.) Mart. & Bignoniaceae & & & & & & 4 \\
\hline Citharexylum myrianthum Cham. & Verbenaceae & 4 & 4 & 11 & 7 & 10 & 8 \\
\hline Dalbergia brasiliensis Vogel & Fabaceae & 2 & & & & & \\
\hline Dalbergia nigra (Vell.)Allemão ex Benth. & Fabaceae & & & & & 5 & 15 \\
\hline Enterolobium contortisiliquum (Vell.) Morong & Fabaceae & & 2 & & & 16 & 9 \\
\hline Eremanthus erythropappus (DC.) McLeish & Asteraceae & 4 & & & & & 4 \\
\hline Eugenia uniflora L. & Myrtaceae & & & & & 12 & \\
\hline Gallesia integrifolia (Spreng.) Harms & Phytolaccaceae & & & & & & 8 \\
\hline Garcinia gardneriana (Planch. \& Triana) Zappi & Clusiaceae & & & & & 14 & \\
\hline Genipa americana $\mathrm{L}$. & Rubiaceae & 15 & 6 & 5 & & & \\
\hline Handroanthus serratifolius (Vahl) S. Grose. & Bignoniaceae & & & & & 6 & \\
\hline Handroanthus chrysotrichus (Mart. ex DC.) Mattos & Bignoniaceae & & 5 & 18 & 15 & & \\
\hline Handroanthus impetiginosus (Mart. ex DC.) Mattos & Bignoniaceae & & & & & & 4 \\
\hline Hymenaea courbaril L. & Fabaceae & 13 & 3 & 8 & 14 & 26 & 7 \\
\hline Ilex cerasifolia Reissek & Aquifoliaceae & & & & & & 6 \\
\hline Inga vera Willd & Fabaceae & 28 & 18 & 28 & & & \\
\hline Jacaranda mimosifolia D. Don & Bignoniaceae & & & & & & 12 \\
\hline Joannesia princeps Vell. & Euphorbiaceae & & & 7 & 13 & 12 & 4 \\
\hline Lecythis pisonis Cambess. & Lecythidaceae & 6 & & 11 & 3 & 15 & 4 \\
\hline Machaerium nyctitans (Vell.) Benth. & Fabaceae & & & & & 15 & \\
\hline Metrodorea nigra A. St.-Hil. & Rutaceae & 16 & 17 & 8 & & & \\
\hline Astronium urundeuva (M. Allemão) Engl. & Anacardiaceae & & & & & & 18 \\
\hline $\begin{array}{l}\text { Paubrasilia echinata (Lam.) Gagnon, H.C. Lima \& G.P. } \\
\text { Lewis }\end{array}$ & Fabaceae & & & & & 12 & \\
\hline Peltophorum dubium (Spreng.) Taub. & Fabaceae & 41 & 31 & 21 & & 34 & 15 \\
\hline Piptadenia gonoacantha (Mart.) J.F. Macbr. & Fabaceae & & & 3 & & & \\
\hline Chloroleucon tortum (Mart.) Pittier & Fabaceae & & & & & & \\
\hline Plathymenia reticulata Benth. & Fabaceae & 5 & & & 10 & & \\
\hline Pseudopiptadenia contorta (DC.) G.P. Lewis \& M.P. Lima & Fabaceae & 17 & 2 & & & & \\
\hline Psidium cattleyanum Sabine & Myrtaceae & 3 & 2 & & & 10 & \\
\hline Psidium guajava L. & Myrtaceae & 3 & & & & 13 & \\
\hline Samanea inopinata (Harms) Barneby \& J.W. Grimes & Fabaceae & & & 19 & 8 & & \\
\hline Sapindus saponaria L. & Sapindaceae & 6 & 4 & & 14 & 17 & \\
\hline Schinus molle L. & Anacardiaceae & 5 & & & & & 17 \\
\hline Schinus terebinthifolia Raddi & Anacardiaceae & 2 & & 18 & 20 & 14 & \\
\hline Schizolobium parabyba (Vell.) Blake & Fabaceae & & & & 13 & & 9 \\
\hline $\begin{array}{l}\text { Senna macranthera (DC. ex Collad.) H.S. Irwin \& } \\
\text { Barneby }\end{array}$ & Fabaceae & 6 & 3 & & 13 & & 3 \\
\hline Sterculia striata A. St.-Hil. \& Naudin & Malvaceae & & & & 7 & 8 & \\
\hline Sysygium cumini (L.) Skeels & Myrtaceae & 3 & & 18 & & & \\
\hline Tabebuia roseoalba (Ridl.) Sandwith & Bignoniaceae & & & & & & \\
\hline Pleroma granulosum (Desr.) D. Don & Melastomataceae & & & & 5 & 5 & \\
\hline Zeyheria tuberculosa (Vell.) Bureau ex Verl. & Bignoniaceae & 14 & 6 & 6 & & & 9 \\
\hline
\end{tabular}


Leaf-cutter ants perform activities inside and outside the colony (ELIZALDE; SUPERINA, 2019), in view of this, physiological, behavioral and foraging aspects are relevant points in their control, which is based on the use of sulfluramid based compounds (FERRO et al., 2018). The results obtained in this study are directly related to the daily life of the implantation of carbon offset plantations in areas with intense attacks by leaf-cutter ants. A possible strategy to be adopted from these results to minimize the losses caused by leaf-cutter ants is the use of species resistant to the attacks
(FOELKEL, 2009), which occur mostly in hot and rainy periods (MACEDO; LANGENHEIM, 1989).

In the 4-year planting, Ceiba speciosa and Handroanthus chrysotrichus were the species with the highest DI. Schinus terebinthifolia and Cariniana legalis were the most resistant to the attack of leaf-cutter ants. The 5-year planting, Ceiba speciosa and Handroanthus serratifolius were the species with the highest DI, and Schinus terebinthifolia and Dalbergia nigra were those with the lowest DI (Table 4).

Table 3. Five species with the highest damage index in plantations 1, 2, 3, 4, 5 and 6.

Tabela 3. Cinco espécies com maior índice de dano nos plantios 1. 2, 3, 4, 5 e 6 .

\begin{tabular}{|c|c|c|c|c|c|c|c|}
\hline \multicolumn{4}{|c|}{ Planting 1 (2010) } & \multicolumn{4}{|c|}{ Planting 2 (2011) } \\
\hline Specie & MS & FA & ID & Specie & MS & FA & ID \\
\hline Z. tuberculosa & 0,97 & 1,00 & 0,97 & C. myrianthum & 1,25 & 1,00 & 1,25 \\
\hline D. brasiliensis & 0,92 & 1,00 & 0,92 & P. granulosum & 1,08 & 1,00 & 1,08 \\
\hline A. pavonina & 0,85 & 0,82 & 0,70 & G. infundibuliformis & 1,03 & 1,00 & 1,03 \\
\hline I. vera & 0,71 & 0,93 & 0,66 & H. chrysotricha & 1,00 & 1,00 & 1,00 \\
\hline S. saponaria & 0,57 & 0,83 & 0,47 & A. pavonina & 1,22 & 0,67 & 0,82 \\
\hline \multicolumn{3}{|c|}{ Planting 3 (2012) } & \multicolumn{5}{|c|}{ Planting 4 (2013) } \\
\hline Specie & MS & FA & ID & Specie & MS & FA & ID \\
\hline C. speciosa & 2,85 & 1,00 & 2,85 & C. speciosa & 1,20 & 1,00 & 1,20 \\
\hline C. myrianthum & 1,97 & 1,00 & 1,97 & H. chrysotricha & 0,76 & 1,00 & 0,76 \\
\hline G. infundibuliformis & 1,40 & 1,00 & 1,40 & B. glabra & 0,70 & 1,00 & 0,70 \\
\hline S. inopinata & 1,24 & 1,00 & 1,24 & C. myrianthum & 0,69 & 1,00 & 0,69 \\
\hline P. gonoacantha & 1,08 & 1,00 & 1,08 & C. glandulosa & 0,62 & 0,92 & 0,57 \\
\hline \multicolumn{4}{|c|}{ Planting 5 (2014) } & \multicolumn{4}{|c|}{ Planting 6 (2015) } \\
\hline Specie & MS & FA & ID & Specie & MS & FA & ID \\
\hline C. speciosa & 1,63 & 1,00 & 1,63 & G.integrifolia & 1,25 & 1,00 & 1,25 \\
\hline H. serratifolius & 0,78 & 0,78 & 0,61 & L. pisonis & 0,92 & 1,00 & 0,92 \\
\hline P. echinata & 0,58 & 0,83 & 0,48 & I. cerasifolia & 0,89 & 1,00 & 0,89 \\
\hline C. tomentosum & 0,60 & 0,67 & 0,40 & C. antisyphilitica & 0,88 & 1,00 & 0,88 \\
\hline B. glabra & 0,52 & 0,75 & 0,39 & B. glabra & 0,65 & 0,87 & 0,57 \\
\hline
\end{tabular}

Table 4. Five species with the lowest damage index in plantations 1, 2, 3, 4, 5 and 6

Tabela 4. Cinco espécies com maior índice de dano nos plantios 1. 2, 3, 4, 5 e 6.

\begin{tabular}{|c|c|c|c|c|c|c|c|}
\hline \multicolumn{4}{|c|}{ Planting 1 (2010) } & \multicolumn{4}{|c|}{ Planting 2 (2011) } \\
\hline Specie & MS & FA & ID & Specie & MS & $\mathrm{FA}$ & ID \\
\hline P. cattleianum & 0,00 & 0,00 & 0,00 & A. macrocarpa & 0,02 & 0,10 & 0,00 \\
\hline S. molle & 0,00 & 0,00 & 0,00 & M. nigra & 0,03 & 0,06 & 0,00 \\
\hline E. erythropappus & 0,00 & 0,00 & 0,00 & A. hassleri & 0,03 & 0,06 & 0,00 \\
\hline C. fissilis & 0,00 & 0,00 & 0,00 & P. dubium & 0,03 & 0,01 & 0,00 \\
\hline S. jambolanum & 0,00 & 0,00 & 0,00 & P. contorta & 0,00 & 0,00 & 0,00 \\
\hline \multicolumn{4}{|c|}{ Planting 3 (2012) } & \multicolumn{4}{|c|}{ Planting 4 (2013) } \\
\hline H.courbaril & 0,14 & 0,88 & 0,12 & S. macranthera & 0,07 & 0,23 & 0,02 \\
\hline A. hassleri & 0,17 & 0,67 & 0,11 & C. grandis & 0,05 & 0,15 & 0,01 \\
\hline A. macrocarpa & 0,08 & 0,38 & 0,03 & A. macrocarpa & 0,01 & 0,07 & 0,00 \\
\hline P. dubium & 0,07 & 0,24 & 0,02 & S. tererebinthifolius & 0,00 & 0,00 & 0,00 \\
\hline S. terebinthifolius & 0,03 & 0,33 & 0,01 & C. legalis & 0,00 & 0,00 & 0,00 \\
\hline H.courbaril & 0,14 & 0,88 & 0,12 & S. macranthera & 0,07 & 0,23 & 0,02 \\
\hline \multicolumn{4}{|c|}{ Planting 5 (2014) } & \multicolumn{4}{|c|}{ Planting 6 (2015) } \\
\hline Specie & MS & FA & ID & Specie & MS & FA & ID \\
\hline A. macrocarpa & 0,05 & 0,31 & 0,02 & E. erythropappus & 0,06 & 0,25 & 0,02 \\
\hline P. dubium & 0,07 & 0,21 & 0,02 & P. dubium & 0,06 & 0,20 & 0,01 \\
\hline G. gardneriana & 0,04 & 0,01 & 0,00 & S. molle & 0,01 & 0,12 & 0,00 \\
\hline S. terebinthifolius & 0,03 & 0,14 & 0,00 & M.urundewva & 0,01 & 0,06 & 0,00 \\
\hline D. nigra & 0,02 & 0,20 & 0,00 & D. nigra & 0,00 & 0,00 & 0,00 \\
\hline
\end{tabular}




\section{DISCUSSION}

The list can provide bases for indicating more resistant species, which can decrease costs associated with replanting and maintenance in carbon neutralization projects. In the present study there is no pattern of attack according to the level of ecological succession of the species, and it is not possible to generalize based on this question. The mean of severity varied between species, which indicates selective foraging (COSTA et al., 2019; COSTA et al., 2017).

The number of species classified as indicated for GHG neutralization plantations were 24 , and 22 were classified as not indicated. The group of species with DI between 0.04 and 0.39 can be seen as an indicator of the species that should be used primarily in places where leaf-cutter ants are an ecological filter to be overcome.

The behavior of ants is variable, which are classified as generalists (BEGON; TOWNSEND, 2021), and as selectives (WIRTH et al., 2007), according to the species preference. In the current study, it was observed that leaf-cutter ants cut leaves from most species, but the foraging was not the same among them. These results show a behavior that is better explained by the optimal foraging theory, where leaf-cutter ants collect from all potential food sources so that the colonies can have an idea of food distribution and, thus, they become aware of the best cost-benefit choices, that is, many plant species are visited by ants, but foraging is not concentrated in all of them (BEGON; TOWNSEND, 2021).

Based on this behavior, the diet of leaf-cutter ants is influenced by the richness of species in the plant community, in other words, the more diverse the community is, more species will be included in the foraging (DEL-CLARO; TOREZAN-SILINGARDI, 2012). The differences in the frequency and intensity of attacks between species are probably related to evolutionary aspects in plant defense (KOST et al., 2011).

Schinus molle, Schinus terebinthifolia, Pseudopiptadenia contorta, Copaifera langsdorffi, Cariniana legalis, Platonia insignis and Astronium urundeuva are species with DI less than 0.04 and that are indicated for mixed plantations. They were also classified in another group of species, because they may have potential for studies to discover natural insecticides, taking into account the natural rejection of ants by these species.

The species Adenanthera pavonina, Pachira glabra, Citharexylum myrianthum, Ceiba speciosa, Cybistax antisyphilitica, Dalbergia brasiliensis, Enterolobium contortisiliquum, Gallesia integrifolia, Genipa americana, Handroanthus serratifolius, Handroanthus chrysotrichus, Ilex cerasifolia, Inga vera, Joannesia princeps, Lecythis pisonis, Metrodorea nigra, Piptadenia gonoacantha, Samanea inopinata, Sapindus saponaria, Senna macranthera, Pleroma granulosum, Zeyberya tuberculosa with DI greater than 0.60, should be avoided. It is recommended to avoid these species in plantations for carbon neutralization in areas with intense attack of leaf-cutter ants.

The presence of specific toxic constituents such as saponins or aluminum also influences the foraging of leafcutter ants (FOLGARAIT et al., 1996). Less attacked species, with DI below 0.04, such as anacardiaceae Schinus molle, Schinus terenbinthifolia, Astronium urundeuva and the Copaifera langsdorffi, Cariniana legalis and Garcinia gardneriana, may be an indicative of species that contain those compounds, as they are naturally avoided by leaf cutting ants.

Centrolobium tomentosum, Psidium cattleyanum, Paubrasilia echinata, Sterculia striata, Andira anthelmia and Colubrina glandulosa were classified in the group of those moderately indicated with DI between 0.60 and 0.40 . Plantations aiming to neutralize GHG emissions from any activity are effective, and the choice of species with greater resistance to ant attack contributes to a greater success of these plantations. This fact reinforces the need to conduct studies that relate the susceptibility of forest species to the damage caused by leafcutter ants.

\section{CONCLUSIONS}

Most species (98.3\%) are attacked by leaf-cutter ants and the mean of severity varied, indicating selective foraging. This makes it possible to classify the species in: 29 in the group of those not indicated, and within this group 7 of the species have potential for the extraction of chemical compounds, 6 in the group of moderately indicated, 24 in the group of indicated, which proves the selectivity of trees species by leafcutter ants. The use of species resistant to the attack of leafcutter ants should be prioritized to the carbon neutralization project become more successful. On the contrary, those most susceptible species should be avoided.

There are species very resistant or species that are not attacked by leaf-cutter ants. Thus, these species can provide efficient active ingredients in the fight against leaf-cutter ants, so these species can be the target of biochemical and physiological investigations in the search for new formulations of insecticides on the market.

\section{REFERENCES}

ARENAS, A.; ROCES, F. Gardeners and midden workers in leaf-cutting ants learn to avoid plants unsuitable for the fungus at their worksites. Animal Behaviour, v. 115, p. 167-174, 2016.2 DOI: https://doi.org/10.1016/j.anbehav.2016.03.016

BEGON, M.; TOWNSEND, C. R. Ecology: From Individuals to Ecosystems. 5 ed. John Wiley \& Sons, 2021. 864p.

CABRAL, D. de C. Into the bowels of tropical earth: leafcutting ants and the colonial making of agrarian Brazil. Journal of Historical Geography, v. 50, p. 92-105, 2015. DOI: https://doi.org/10.1016/j.jhg.2015.06.014

COLEY, P. D.; BRYANT, J. P.; CHAPIN, F. S. Resource Availability and Plant Antiherbivore Defense. Science, v. 230, n. 4728, p. 895-899, 1985.

COSTA, A. N.; VASCONCELOS, H. L.; BRUNA, E. M. Biotic drivers of seedling establishment in Neotropical savannas: selective granivory and seedling herbivory by leaf-cutter ants as an ecological filter. Journal of Ecology, v. 105, n. 1, p. 132-141, 2017. DOI: https://doi.org/10.1111/1365-2745.12656

COSTA, A. N.; VASCONCELOS, H. L.; VIEIRA-NETO, E. H. M.; BRUNA, E. M. Adaptive foraging of leaf-cutter ants to spatiotemporal changes in resource availability in Neotropical savannas. Ecological Entomology, v. 44, n. 2 p. 227-238, 2019. DOI: https://doi.org/10.1111/een.12697

DEL-CLARO, K.; TOREZAN-SILINGARDI, H. M. Ecologia Das Interações Plantas-Animais: Uma Abordagem Ecológico Evolutiva. 1 ed. Rio de Janeiro: Technical Books Editora, 2012. 336p.

DIMOBE, K.; KUYAH, S.; DABRÉ, Z.; OUÉDRAOGO, A.; THIOMBIANO, A. Diversity-carbon stock relationship across vegetation types in W National Park in Burkina Faso. Forest Ecology and Management, v. 
438, p. 243-254, 2019. DOI: https://doi.org/10.1016/j.foreco.2019.02.027

ELIZALDE, L.; SUPERINA, M. Complementary effects of different predators of leaf-cutting ants: Implications for biological control. Biological Control, v. 128, p. 111117, $2019 . \quad$ DOI: https://doi.org/10.1016/j.biocontrol.2018.09.015

ELIZALDE, L.; TREANOR, D.; PAMMINGER, T.; HUGHES, W. O. H. Immunity of leaf-cutting ants and its role in host-parasitoid relationships. Journal of Insect Physiology, v. 116, p. 49-56, 2019. DOI: https://doi.org/10.1016/j.jinsphys.2019.04.008

FERRO, F. S.; SILVA, D. A. L.; ICIMOTO, F. H.; LAHR, F. A. R.; GONZÁLEZ-GARCÍA, S. Environmental Life Cycle Assessment of industrial pine roundwood production in Brazilian forests. Science of The Total Environment, v. 640-641, p. 599-608, 2018. DOI: https://doi.org/10.1016/j.scitotenv.2018.05.262

FOLGARAIT, P.; DYER, L.; MARQUIS, R.; BRAKER, E. Leaf-cutting ant preferences for five native tropical plantation tree species growing under different light conditions. Entomologia Experimentalis et Applicata, v. 80, p. 521-530, 1996.

KOST, C.; TREMMEL, M.; WIRTH, R. Do Leaf Cutting Ants Cut Undetected? Testing the Effect of Ant-Induced Plant Defences on Foraging Decisions in Atta colombica. PLOS ONE, v. 6, n. 7, e22340, 2011. DOI: https://doi.org/10.1371/journal.pone.0022340

LI, J.; DONG, W.; OENEMA, O.; CHEN, T.; HU, C.; YUAN, H.; ZHAO, L. Irrigation reduces the negative effect of global warming on winter wheat yield and greenhouse gas intensity. Science of The Total Environment, v. 646, p. 290-299, 2019. DOI: https://doi.org/10.1016/j.scitotenv.2018.07.296

MACEDO, C. A.; LANGENHEIM, J. H. A further investigation of leaf sesquiterpene variation in relation to herbivory in two Brazilian populations of Copaifera langsdorfii. Biochemical Systematics and Ecology, v. 17, n. 3, p. 207-216, 1989. DOI: https://doi.org/10.1016/0305-1978(89)90082-3

MAHBUB, N.; GEMECHU, E.; ZHANG, H.; KUMAR, A. The life cycle greenhouse gas emission benefits from alternative uses of biofuel coproducts. Sustainable Energy Technologies and Assessments, v. 34, p. 173186, 2019.2 DOI: https://doi.org/10.1016/j.seta.2019.05.001

MORAIS JUNIOR, V. T. M. DE; JACOVINE, L. A. G.; TORRES, C. M. M. E.; ALVES, E. B. B. M.; PAIVA, H. N. DE; CRUZ, R. A. LA; ZANUNCIO, J. C. Early assessment of tree species with potential for carbon offset plantations in degraded area from the southeastern Brazil. Ecological Indicators, v. 98, p. 854-860, 2019. DOI: https://doi.org/10.1016/j.ecolind.2018.12.004

PETERNELLI, E. F. DE O.; DELLA LUCIA, T. M. C.; MARTINS, S. V. Espécies de formigas que interagem com as sementes de Mabea fistulifera Mart. (Euphorbiaceae). Revista Árvore, v. 28, n. 5, p. 733-738, 2004. DOI: https://doi.org/10.1590/S010067622004000500013
RABELING, C.; MESSER, S.; LACAU, S.; NASCIMENTO, I. C. DO; BACCI, M.; DELABIE, J. H. C. Acromyrmex fowleri: a new inquiline social parasite species of leaf-cutting ants from South America, with a discussion of social parasite biogeography in the Neotropical region. Insectes Sociaux, v. 66, n. 3, p. 435451, 2019. DOI: https://doi.org/10.1007/s00040-01900705-Z

SEGRE, P. S.; TAYLOR, E. D. Large ants don't carry their fair share: Maximal load carrying performance of leafcutter ants (Atta cephalotes). Journal of Experimental Biology, v. 222, eb199240, 2019. DOI: https://doi.org/10.1242/jeb.199240

SINGH, B.; KAUR, A. Control of insect pests in crop plants and stored food grains using plant saponins: A review. LWT, v. 87, p. 93-101, 2018. DOI: https://doi.org/10.1016/j.lwt.2017.08.077

TUBIELLO, F. N.: Greenhouse gas emissions due to agriculture. In: Encyclopedia of Food Security and Sustainability, Amsterdam: Elsevier, 2018. p. 196-205.

WIRTH, R.; MEYER, S. T.; ALMEIDA, W. R.; ARAÚJO, M. V.; BARBOSA, V. S.; LEAL, I. R. Increasing densities of leaf-cutting ants (Atta spp.) with proximity to the edge in a Brazilian Atlantic Forest. Journal of Tropical Ecology, v. 23, n. 4, p. 501-505, 2007. DOI: https://doi.org/10.1017/S0266467407004221

ZANETTI, R.; ZANUNCIO, J. C.; SANTOS, J. C.; SILVA, W. L. P. DA; RIBEIRO, G. T.; LEMES, P. G. An overview of integrated management of leaf-cutting ants (Hymenoptera: Formicidae) in Brazilian forest plantations. Forests, v. 5, p. 439-454, 2014. DOI: https://doi.org/10.3390/f5030439

ZHENG, X.; STREIMIKIENE, D.; BALEZENTIS, T.; MARDANI, A.; CAVALLARO, F.; LIAO, H. A review of greenhouse gas emission profiles, dynamics, and climate change mitigation efforts across the key climate change players. Journal of Cleaner Production, v. 234, $\begin{array}{lccc}\mathrm{p} & .1113-1133, & 2019 . & \text { DOI: }\end{array}$ 